\title{
OPERATIVE DIFFERENCES EISENMAN, TAFURI AND THE LESSON OF PIRANESI
}

\section{A B S T R A C T}

Peter Eisenman is an architect. His field of action, although related to a multiform set of interests, is the investigation of the theoretical foundation of the architectural discipline. Architecture, as an artefact as well as a project, can be seen as the most evident representation of the traditional opposition of Western metaphysics: absence and presence. The task of the architect, according to Eisenman, is therefore to intervene analytically in this dialectical condition and make it operable. From this point of view, Eisenman's approach to the discipline as well as his entire, lifelong architectural journey - is observed in the light of the work of Giovanni Battista Piranesi. Going beyond the critique made by the Italian architecture historian Manfredo Tafuri, Eisenman explored the possibility of a new interpretation of the dialectic between positive and negative, electing the notion of ground as the very place of this opposition. The Berlin Memorial to the Murdered Jews of Europe offers the final representation of this dialectic, opening it to a further, unparalleled working field. 
In his long career, Peter Eisenman's interests have touched many different disciplines: from research to practice, from architecture to urbanism, to education, to history, to philosophy, to literature, to film theory. Nonetheless, even though his work can be seen through several lenses, Eisenman remains an architect whose field of action is a precise and restricted discipline. Indeed, every work of Eisenman, be it built or just theorised, can always be read as a specific attempt to collect and abstract all these differences, reading them in pure architectural terms: architecture, for Eisenman, is therefore a philosophical practice in itself. From that point a view, differences do not need to be translated from one field to another; they simply constitute the essence of that practice.

The device that has always allowed Eisenman to make these differences operative - and which basically defines all architecture - is the project. Indeed, the project is, by definition, a projection towards a new status, i.e. something never completely realised that at the same time unifies and separates the space between architecture and reality. In this way, the project opens up a fracture, a space of crisis between the fundamental incompleteness of this process and the condition of its operability. The task of the architect, according to Eisenman, is precisely to intervene in this fracture.

\section{ANALYSIS}

In 1961, Peter Eisenman travelled through Italy together with Colin Rowe, a professor at Cambridge University, where Eisenman was taking his PhD. In this occasion he discovered something even more important than his beloved Italian masters - from Palladio to Terragni, from Raphael to Guido Reni. As already Le Corbusier had understood during his first travels, architecture is nothing more than a way of observing reality; and this observation is analytical, grounded on the identity of the architectural object, on its separation from the context and on its comparison with other examples. Yet these differences do not exist outside the process of formal analysis in which they are generated. Architecture can be therefore described as a device aimed not simply at surveying differences, but ultimately at producing them.

Starting from his $\mathrm{PhD}$ thesis, The Formal Basis of Modern Architecture, submitted in August 1963, Eisenman progressively demonstrated how the project is the device that activates the analysis and makes the differences operative; it is the project, in fact, that gives to the identified variables a physical and theoretical - although never definitive - stability. In this context, 
Terragni's Casa del Fascio was not just an object of formal analysis, but more properly Peter Eisenman's very first architectural project, whose outcomes he will bring along for the rest of his career.

Eisenman's analytical approach to Terragni's work and to the legacy of modern architecture reflects an analogous attitude of Giovanni Battista Piranesi towards Roman antiquities and, more generally, the heritage of the past. The Venetian architect moved to Rome in 1740 and started a lifelong research of the characters of its classical architecture. In the famous series of etchings titled Il Campo Marzio dell'Antica Roma, published in 1762, Piranesi reached the acme of his project proposing a hypothetical reconstruction of the ancient centre of Rome; this operation was supported by a careful survey of the existing ruins, together with a detailed investigation of the form and location of the ancient monuments. Yet Piranesi rejected the idea of treating the city as a mere container of artefacts, cataloguing the Roman antiquities according to a scientific and neutral way. Consequently, he showed how history, in order to be a valid analytical tool, must be projected on the present condition. The architectural project, for him, is therefore the means that produces a condition of operability starting from the spatial and temporal differences of the historic reality. In this way, the city becomes precisely the place where this relationship can be read and understood.

Not surprisingly, the Campo Marzio is an answer to another completely different idea of the city only few years elder: the well-known Giovanni

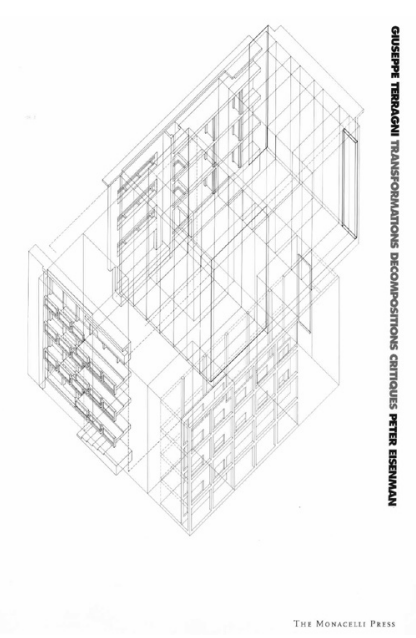

Figure 1. Cover of Peter Eisenman, Giuseppe Terragni: Transformations, Decompositions, Critiques (2003).

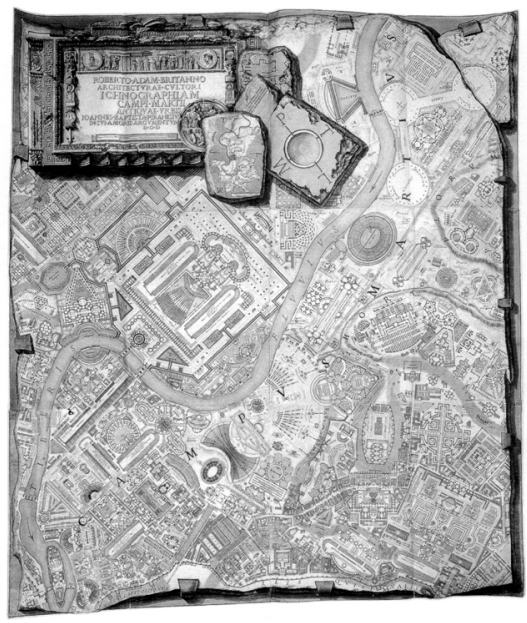

Figure 2. Giovanni Battista Piranesi, Ichnographia of the Campus Martius, from Il Campo Marzio dell'Antica Roma (1762). 
Battista Nolli's Map of Rome published in 1748. Indeed, far from being just a cadastral plan, Nolli's Map can be read as the project that perfectly incorporates the spirit of the Western urbanisation of the last 250 years, presenting the city as a dialectic opposition of blacks and whites: a white rational and measurable - thus exploitable - ground is covered by black poché representing architecture, now interpreted as the positive and productive work of the man of the Enlightenment. This condition - the so-called figure-ground dialectic appears in the Nolli's Map as a powerful device able to clearly represent the classical humanist, rationalist and functionalist approach to reality. Moreover, as Eisenman noticed, Nolli's Map "represents an idea of original truth, of a moment in time that uses this moment in the Eighteenth Century as a badge of authenticity to authorise work in the present"1.

Against the idea of architecture as dialectical relationship between the solid and the void, poché and the ground, presence and absence, the Piranesian Campo Marzio offers a representation where everything is reduced to a single device: no blacks and whites but an articulated figured ground. By contrasting a "figure-ground" to a "figure-figure" 2 model, Eisenman makes clear the differences of the two approaches: to the precision and legibility with whom Nolli depicts architecture as something inscribed in a linear, historical process, Piranesi answered highlighting the partial and discontinuous character of historical time. By defining the Roman antiquities as a set of elements of the past, the Campo Marzio showed how looking at history means having to do with a field of differences that only the present can make operable.

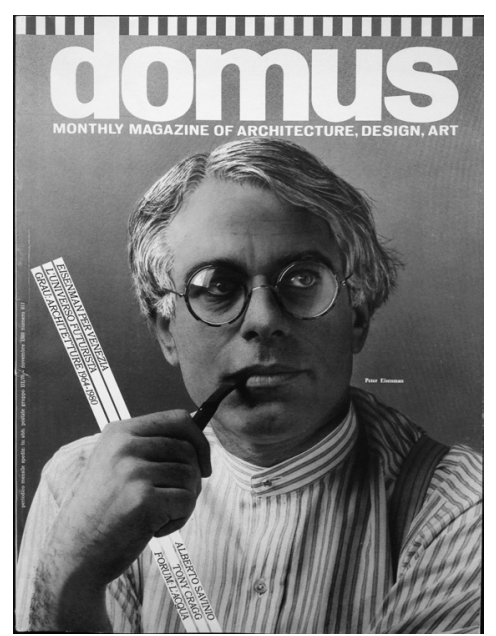

Figure 3. Peter Eisenman on the cover of Domus 611, November 1980.

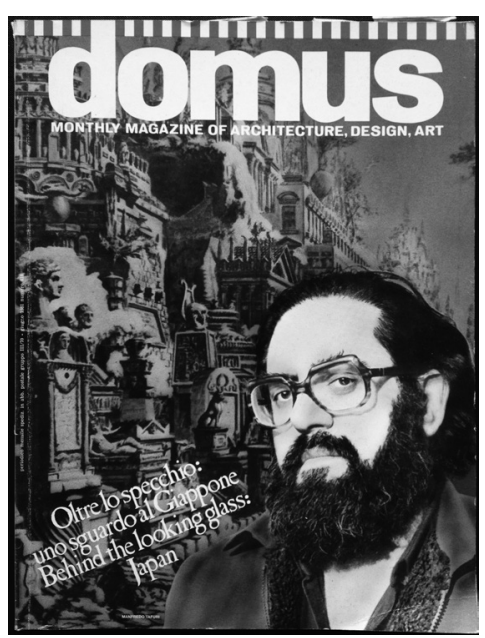

Figure 4. Manfredo Tafuri on the cover of Domus 618, June 1981. 


\section{CRITIQUE}

At the end of the ' 60 s, the work of Giovanni Battista Piranesi had been observed from a very peculiar point of view by the Italian architecture historian Manfredo Tafuri. From his earliest works, Tafuri underlined the pivotal role that Piranesi played in exploring the dark side of the culture of Enlightenment by pushing it to its extreme theoretical limits. In the seminal 1969 article Per una critica dell'ideologia architettonica, Tafuri chose Piranesi as the starting point of the discourse on modern and contemporary architecture, as embedded in the failure of the utopian ideologies of the Age of Reason and the consequent theoretical crisis that has accompanied all bourgeois art since then. According to Tafuri, the crisis was due to the collapsed ambition of bourgeois art to unify Reason and Nature, rational and irrational, city and landscape. Piranesi was among the firsts to show how this crisis is something internal to architecture; it offers no escape, and therefore it must be faced within its domain. The Campo Marzio - but in reality the whole work of the Venetian architect - has been seen by Tafuri as an investigation of "the battle waged by architecture against itself". Not by chance, the shock is the condition of modernity that links Piranesi to the '900 Avant-Gardes. Tafuri defined shock as the moment when "the individual architectural fragments collide with one another, indifferent even to the clash, while their accumulation attests to the uselessness of the inventive effort made to define their form"3. In order to be elaborated, the shock must be internalised as an inevitable condition of existence, that is represented in a comprehensive mechanism capable of reconciling those fragments in a new - although unstable - configuration.

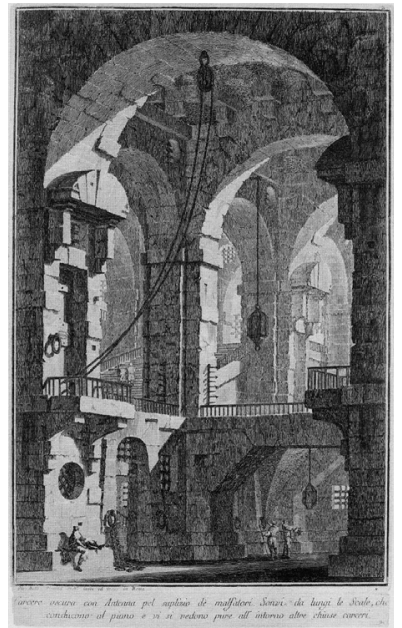

Figure 5. Giovanni Battista Piranesi, Carcere oscura ("The Dark Prison"), ca. 1745.

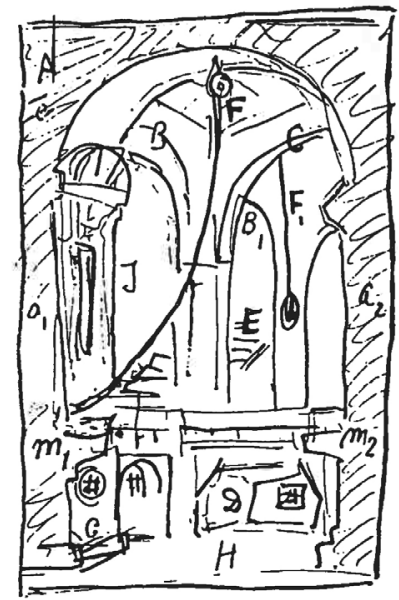

Figure 6 . Diagram by Eisenstein of Piranesi's Carcere oscura. 
A proof of this statement is offered by Tafuri's interpretation of Piranesi's series of Carceri (Prisons), drawn in 1749. In the Carceri the crisis of architecture is evident and definitive, since the project has lost every direct connection to reality. The urban context of the previous series of etchings, with all its historical and symbolical references, is translated into an abstract and a-temporal, internal space, that architecture is no longer able even to represent correctly. More than the suffering figures in the foreground, it is in fact the absurd and paradoxical construction of the image that reveals this fracture. Translating the Carceri's perspectives into plans and sections, Tafuri showed the not-scientific construction hidden behind those apparently normal views: bridges, towers, arches refer all to a completely different system of coordinates; their rendered image is by no point of view plausible. Yet, by arranging such contrasting elements in one single view, Piranesi at the same time proved the impossibility of their co-existence as a 'realistic' whole and the possibility of their existence as an ideological construction. In other words, in the Carceri Piranesi stated that architecture is now free and independent from any realistic concern and context: this declaration of autonomy corresponds to the foundation of the modern avant-garde.

In the Carceri, a further representation of the incipient state of crisis of architecture is given by the failure of its most traditional and constructive notions: architecture's technique is no longer able to solve any problem. Yet, this scientific impasse opened the disciplinary field to an unprecedented role of the architect - what Tafuri called the "wicked" architect, of which Piranesi has been the pioneer - as the active protagonist and the new subject of the project.

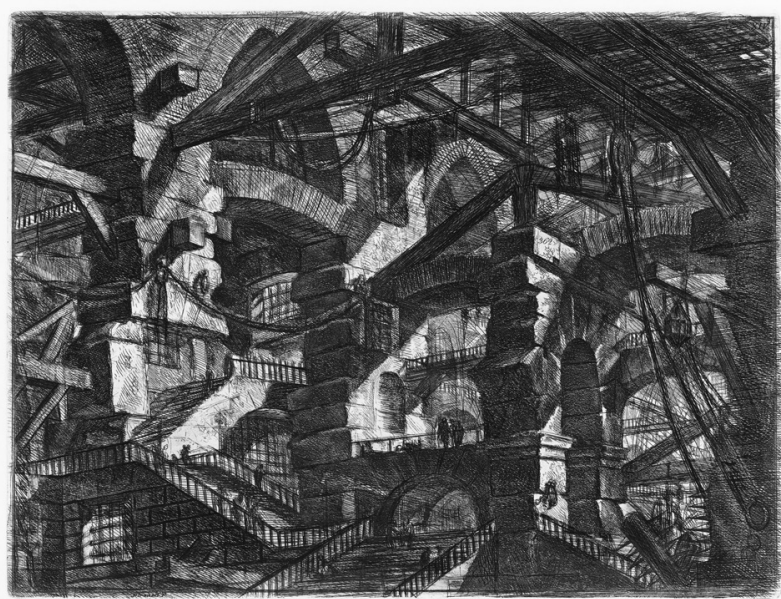

Figure 7. Giovanni Battista Piranesi, Carceri Series Plate XIV (1745) 
After all, as Tafuri stated, "history no longer offers values as such. [...] It is the experience of the subject that establishes values"4. Nevertheless, from the $18^{\text {th }}$ Century on, the subject is by definition alienated and confined in a mechanical universe where there are no fixed values and no defined goals to represent. Technique becomes an end in itself, technique pour technique.

With the essay The Dialectic of the Avant-Garde: Piranesi and Eisenstein ${ }^{5}$, published in Oppositions - the magazine founded and directed by Peter Eisenman from 1973 to 1984 - Tafuri uses the figure of the Russian director to enlighten Piranesi's approach to the construction of the image. Studying Piranesi's Carcere Oscura (Dark Prison) Eisenstein proves in fact that the composition of the image happens through a sequence of operations, i.e. through a montage, which is completely arbitrary and evidently artificial. The technique is ultimately reduced to a manipulation of the very medium of representation: this is the place in which architecture affirms his power. By unveiling the strategy that underlies the work of Piranesi, Eisenstein's critique of the artwork becomes direct action on the artwork itself. Through Eisenstein, Tafuri explained how in the modern project differences are exorcised by the process of montage, which can in turn celebrate or camouflage them. Taking advantage of that, the image, far from being only an artefact, is an operative device able to influence knowledge and actions and to provoke shocked reactions in its public.

Furthermore, the arbitrary and the artificial nature of the montage highlighted the definitive death of any architectural system of knowledge, of any architectural language. And once again, Tafuri identified in Piranesi the figure in charge of announcing this death: "The ambiguity of the Campo Marzio now becomes evident; it is at once a 'project' and a denunciation. [...] Inasmuch as it is - despite everything - an affirmation of a world of forms, the Campo Marzio, precisely because of the absurdity of its horror vacui, becomes a demand for language, a paradoxical revelation of its absence"6.

According to Tafuri, Piranesi's project, far from being just an exercise of eclecticism, hides the most rigorous acceptance of the aberrant, dark side of reality. The dissolution of form, as explored in the Campo Marzio and - in a more conceptual way - in the Carceri, makes visible the absence of signification and the impossibility of any coherent alternative, while at the same time presenting this "negative" as such. The "construction of a utopia of dissolved form" thus implies, for Tafuri, a demand for "the recuperation of this negative, the attempt to utilise it." 
In the mid '70s, this 'demand' is exactly what Aldo Rossi and Peter Eisenman challenged in their work. On the one side Aldo Rossi was trying, in fact, to bring the discourse on architectural form back to its symbolical essence. He investigated therefore the possibility of memory, as the thread able to join conscious and unconscious, individual and collective, architecture and city. In this spirit, in 1976 Rossi produced the Città Analoga, a collage of indifferently assembled maps, platonic solids, realised and not realised projects, sentimental objects and much more. Once the language of the city has lost all its meanings - as well as its ability to produce new ones - everyone's memory is in charge of creating new forms and significations.

From a different point of view, the philosopher Jacques Derrida was investigating a different form of memory, not involved with fragmentation or abstraction, but intended as a device related to language. Derrida called it "trace": "The trace is not a presence but is rather the simulacrum of a presence that dislocates, displaces, and refers beyond itself. The trace has, properly speaking, no place"s. In this way, the trace reveals itself as the presence of an absence; not an absence as something dialectically opposed to presence, but rather something that goes beyond the dialectic itself. Following Derrida, Eisenman worked on the possibility of an (architectural) language which is not representing a reality external to itself, but intended as an ecriture, a positive process internal to the language that produces meanings no more referring to any stable, absolute system of values. This shift presupposes a radical change: language, once a unitary structure able to correspond with a common set of notions, had to be turned into text, something not related to any context, but able to redefine the context according to its internal grammar. The text becomes the ground where architects can operate: the project is therefore the production of different layers of meaning, of a set of traces recording the various phases of the process.

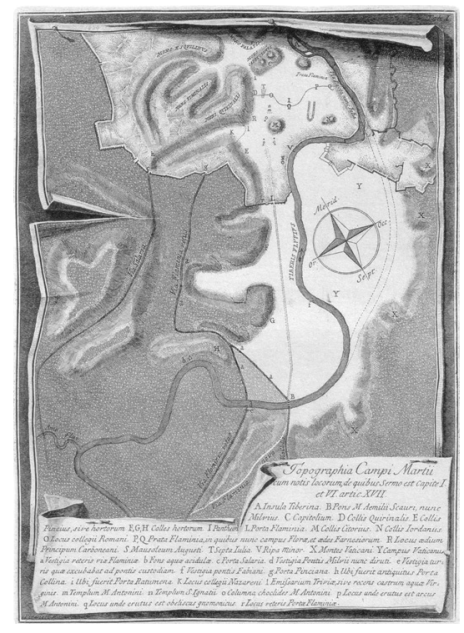




\section{TOPOGRAPHY}

The construction of a new, autonomous ground of operability characterised all of Piranesi's work. Instead of accepting all rational and scientific conventions developed throughout the Enlightenment, Piranesi explored the definition of a new form of spatial and historical conditions. In order to better understand this process, it is useful to look at the Topographia of the Campo Marzio, assuming it as a sort of precondition for the better-known Ichnographia, the very place where it found its formal basis. Indeed, the word topography, deriving from the ancient Greek, is formed by two different words: topos (place) and graphia (writing). Precisely this 'writing of the place' shows the approach that underlies the apparently chaotic representation of the Ichnographia: the Topographia is then that ground where all the different architectural elements are isolated and analysed.

Piranesi's reading of the city is made through simple and clear categories, catalogued not according to their features but to their mere existence, here interpreted as a physical, mythological or just imaginary condition. This choice allowed him to ignore any chronological and typological category, collecting in the same plates morphological elements, infrastructures, existing or fictional monuments and ruins. In this new configuration, buildings represent only themselves, completely separated from their traditional historical and functional values. Piranesi, with his ultimately indexical approach, is perfectly aware of the impossibility of representing any 'true' reality, joining real and imaginary, space and time, rational and irrational in a objective, reassuring image. By displaying such polarities, he shows, with clarity never before seen, that between the two poles of Western metaphysics - presence and absence there is a void as concrete as it is unbridgeable.

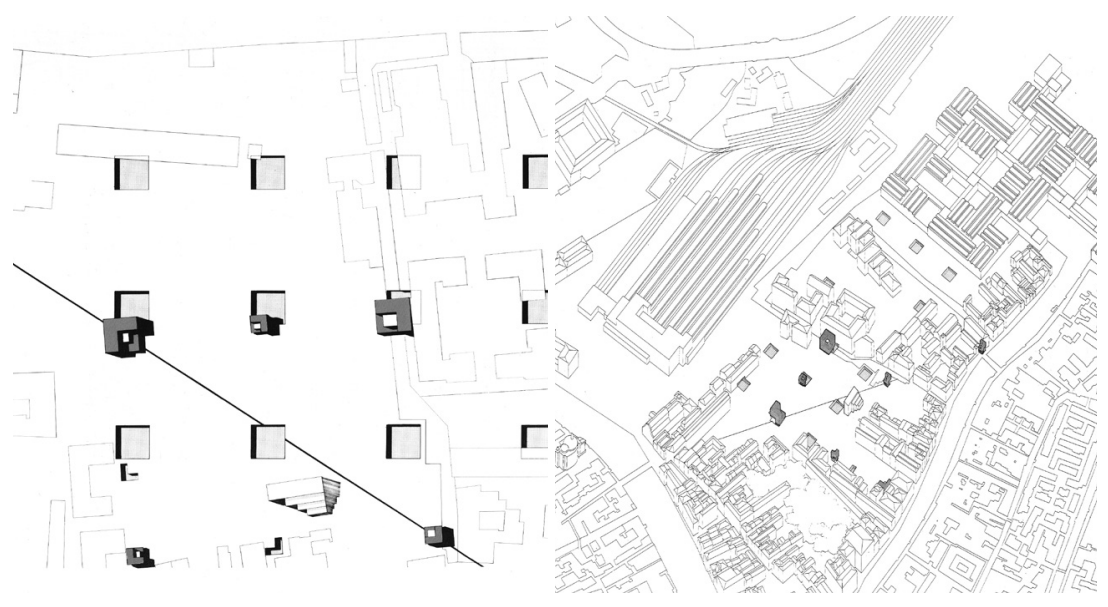


In this sense, Eisenman's project for Cannaregio in 1978 marked an important turning point in the career of the New York architect after the previous season of the Houses, which were architectural objects consciously indifferent and autonomous from any theorisation of space and time, context and persistence. Invited by Francesco dal Co to take part in 10 immagini per Venezia (10 Images for Venice), an international workshop to rethink the district of Cannaregio, Eisenman proposed a pretty indexical approach to the urban history of Venice, taking into consideration both real and imaginary pre-existences. On the one side the never realised Le Corbusier's Hospital provided the grid for the new project; on the other, the existing context was taken almost indifferently, as a sort of definitive and immutable limit to the intervention. In this 'context' the previous experience of the Houses - in particular the House XI - offers the palimpsest for the new project, without being influenced by any chronological and typological definition deriving from the urban history. No stable and safe connection is possible between Venice - a specific and stratified space and time condition - and the new project exactly because this connection is too strong, too vast and too concrete to be represented. The only possible way to intervene, then, is writing a new text. In the voids that mark the Cannaregio area, Eisenman is thus reinterpreting the Piranesian 'projective archaeology', where traces from the past, the present and the future are collected, interpreted, written and finally left back on the ground.

This passage makes apparent how exactly the ground becomes now the fundamental topos where the differences of the city - its conditions of operability - are collected and projected with a new graphia. The ground enables a topography that binds together what exists, what does not exist

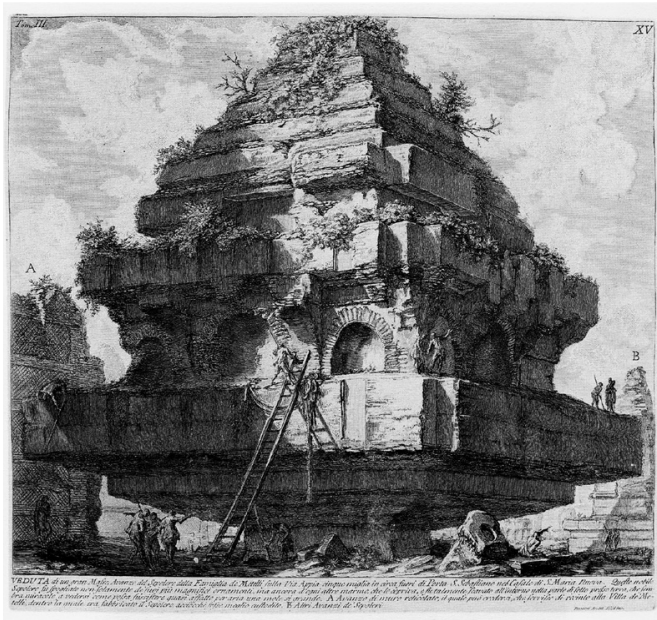

Figure 9. Giovanni Battista Piranesi,

Remains of the tomb of the Metelli, from Le Antichità Romane (1756)

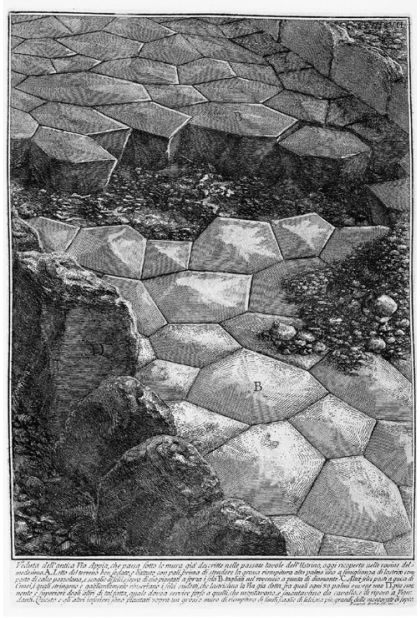

Figure 10. Giovanni Battista Piranesi, View of the Via Appia Antica, from Le Antichità Romane (1756) 
(anymore) and what only could. Since then, the ground will always play a pivotal role in all Eisenman's works. On the one hand, in projects like Romeo + Juliet in Verona and Parc de la Villette competition in Paris, the ground was still intended as a text, in its physical sense of two-dimensional tabula where it is possible to read and write different signs of time. On the other hand, in more recent works the ground relates to the idea of 'artefact': a three-dimensional object where it is possible to excavate and reveal new materials and meanings. Initially introduced as a condition for the project, in most recent works such as the City of Culture of Galicia, the ground becomes the very place where the traces of the design process are instrumentalised in order to produce a new kind of space: a figure-figure composition arising from the ground and remaining embedded in it; actually, a ground-ground model.

In this process of 'artificial excavation' the differences, once belonging to the abstraction of architecture grammar, start to be investigated in their temporal dimension: under the light of history the ground becomes a project in itself.

The Sepolcro della Famiglia Metelli (Tomb of the Metelli Family) - an etching from Le antichità romane by Piranesi - is the best example to express how architecture can be produced only by physical 'difference'. The progressive erosion of the original artefact, used as a quarry of reclaimed bricks in the Middle Ages, shows how subtracting parts means transforming the old building into a new one while 'projecting' a new form for the old building; on a more proper historical layer, this process could also be read as the grounding of the present onto the past while transforming the past into what the present needs.

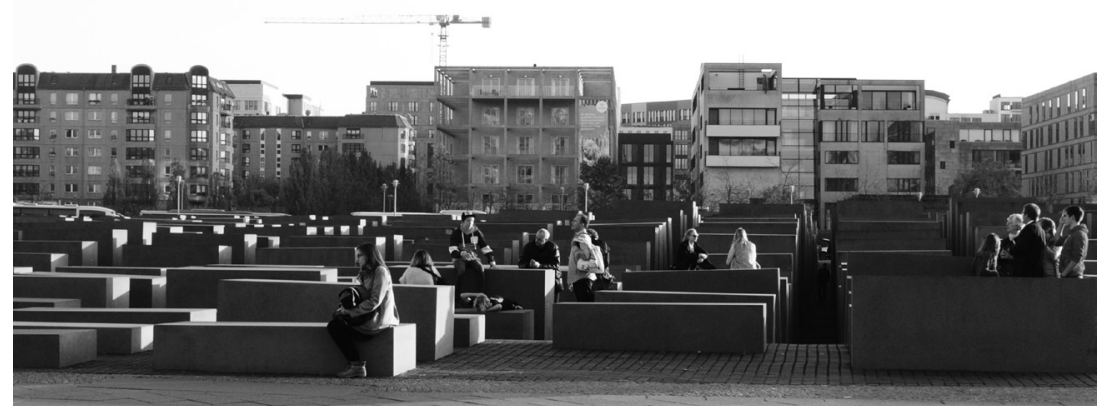

Figure 11. Peter Eisenman, Memorial to the Murdered Jews of Europe, Berlin (2005).

Photo Alessandro Toti. 
The interpretation of the past, its value, is here directly related to the physical trace of its transformation. In Piranesi's etchings, the memory of the Metelli tomb is then transfigured into an object that records the struggle between the symbolical survival of the monument and the destructive passage of time. As Walter Benjamin in its sixth thesis from On the Concept of History reminds: "To articulate what is past does not mean to recognise 'how it really was'. It means to take control of a memory, as it flashes in a moment of danger"'.

Nonetheless, there is another etching from Le antichità romane, where Piranesi applied the same argument directly to the concept of the ground. Indeed, in the excavations from the via Appia Antica, Piranesi reveals his interest for the internal value of the ground, assumed now as an autonomous element. On the one side Piranesi is always keen on highlighting the engineering nature of architecture: several drawings of streets, walls, aqueducts and bridges bear witness to the strong fascination of the Venetian architect with the technical dimension of architecture. In fact, his father was a stonemason and he grew up in the workshop of his uncle Matteo Lucchesi, an engineer for the Water Magistrate of Venice, when the latter was working on the murazzi, the sea walls that protected the city from the flood of the lagoon.

Nevertheless, the image of via Appia Antica displays something more: the street, as every artefact, has its own depth, namely the structure of the pavement; in the picture Piranesi calls this depth the "B" level. Hidden beneath it there is another level, i.e. the " $\mathrm{A}$ " one. This lower, yet first and necessary ground is nothing but the earth, personifying all the forces that both support and oppose the human - or simply architectural - endeavour of defining reality. With his efforts man can try to cover this layer more or less properly, to make it more confortable and exploitable, but it will always be down there without any possibility to be removed.

The street, as a manufactured, human ground, more than being just a horizontal surface, is therefore an obstacle between the present and the past, activity and passivity, reality and its phantoms. Yet, as the Italian philosopher Giorgio Agamben highlighted, the traditional oppositions of Western metaphysics appearance and essence, signifier and signified, sensible and intelligible - are not self-excluding, but they both exist in a relationship of reciprocal negation. This dual existence is not a contradiction, nor a generic compromise towards a 'third way'; on the contrary, it is the very condition in which man can appropriate the incomprehensible and make it operable. This is possible only by separating the opposites through an object able to resist whatever 'original' 
and 'final' definition, a space able to shield the dual, enigmatic and ultimate ungraspable dimension of the signification. This space, which Agamben calls "barrier" ${ }^{10}$, is precisely what he put in evidence in Eisenman's project for the Berlin Memorial.

\section{SUBJECT}

The competition for the Memorial to the Murdered Jews of Europe - launched in 1994 and changed many times until the final completion of the project in 2005 - presented the difficult task of both representing the indescribable tragedy of the Holocaust and archiving the boundless research materials of the dramatic historical event. "In the Monument - commented Agamben these two heterogeneous dimensions of the memory are topographically distinguished: over the ground the absolutely unreadable steles, under the ground an information centre, devoted solely to reading. The immaterial barrier, dividing these two kinds of memories, is the very place of the Monument"11 Eisenman's project, therefore, is only the barrier, the representation of the differences existing upon its two layers: in this case, put simply, the readable vs. the unreadable. But if the design of the 'readable' - a rational and concluded part, that clearly communicates its meaning - has been a quite ordinary task for architecture of the last three centuries, it is the definition of the 'unreadable' that is the really challenging aspect for Peter Eisenman as an architect.

With its slightly pending 2711 concrete steles of different height, the Memorial is completely indecipherable and in no way directly related to the Jewish tragedy. In this way, Eisenman rejects any significant representation of the 'monument': no Venturi's graspable and consumable icons, no Rossi's introverted and rational figures, no Koolhaas's proud and autonomous monoliths. Only silence is surrounding the steles, only light is filling the voids between them. Nevertheless, by radicalising its absolute abstraction and anonymity, the Memorial is not abandoning any form of real life; on the contrary, it is opening up a space for what Paolo Virno called "unicity without aura" 12 . According to Virno, in the contemporary society the production of differences, the 'unexampled', can only arise from the most conventional and standardised rules. Unicity is nothing but the sheer product of seriality. In this monument, unicity arises from the possibility of freely inhabiting this anonymous space. In fact, by being opened to any activities, visitors - or, better said, people - are not forced to remember any history or to learn any moral: historicism and didacticism are replaced by the exemplary value of human activity; the monument itself contains nothing but the experiences of 


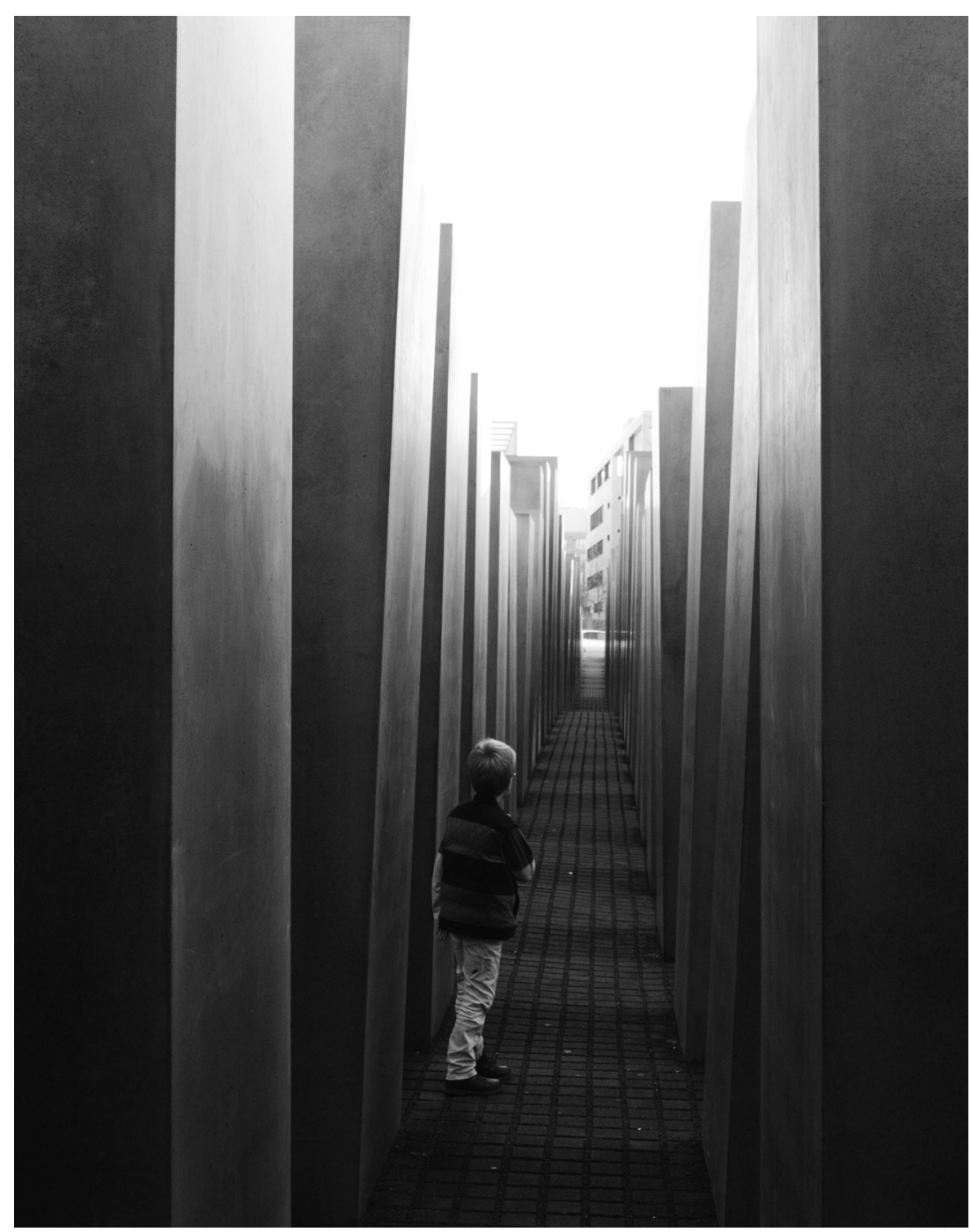

Figure 12. Peter Eisenman, Memorial to the Murdered Jews of Europe, Berlin (2005). Photo Alessandro Toti. 
everyone's everyday life. Thus, as it was for the Tomb of the Metelli Family, a concrete history becomes now the basis from which new forms of life are created. From the ground it is again possible to subtract precious elements to build the present: in Rome in the form of bricks or stones, in Berlin in the form of experiences and memories. But exactly as discovered by Piranesi, once those elements are brought back under the light of the present, one discovers that there is no precise and defined way to use them; as Virno argues: "The experience is an end in itself" ${ }^{\prime 13}$. In this way the Memorial refuses to be a place of history - the umpteenth Museum of Modern History - in order to become a place of everyday life, an unexampled conventional part of the city whose alter ego remains, as in any other part of the city, concealed under the ground.

Underlying the representation of this split is the real project of Eisenman's Berlin Memorial. After having explored and criticised the possibilities of Nolli's figure-ground, of the Piranesian figure-figure and of the Santiago de Compostela ground-ground, the project of the city is no longer left to any dialectical opposition. The positive and the negative, discipline and avantgarde are no more counterpoised, but developed singularly and simultaneously: the real conflict is no more between them but inside them. It does not matter whether the black will become blacker, since the blackest poché will always imply its opposite, a 'white' overflowing of meanings awaiting to be unveiled. Independently from the outcomes of the dialectic, black and white, figure and ground, rational and irrational cannot emancipate one another. Therefore, neither any predominance of one single colour nor any compromising grey is to be sought in Eisenman's Memorial: the struggle of the black against the white here cannot produce anything but a void, a space of im-possibility that will never be completely bridgeable. The ground separating the above from the below, the signifier from the signified, is therefore the perfect representation of what Agamben would call an "immobile dialectic" ${ }^{14}$ : a barrier, enabling the two dialectical oppositions to exist and to express their internal tension as radically as possible, without admitting any contact between them.

Nevertheless, by making inoperative the differences between opposites, the barrier is able to make room for the unveiling of what has always been hidden behind the rigid confrontation of dialectical and ideological statements: a subject able to critically cross the paratactic space of the monoliths discovering the unutterable - yet experiential - value of architecture. This subject, closely observed, is no less than Peter Eisenman himself, intended as the one who has been experiencing this value in his entire, lifelong architectural journey. Indeed, having once discovered that no dialectic can be anything but immobile, having 
once acknowledged it is impossible both to connect and to disconnect the two poles of the contraposition, looking for a 'solution' of the dialectical method becomes meaningless. From the process the attention shifts to the active subject of the process, from the travel between the oppositions to the direct experience of the traveller. Thus, today it is the very life of Peter Eisenman that constitutes his most concrete architectural legacy: from the first exploration across Europe to the discovery of the analytic value of architecture, from the decontextualized housing projects to the decontextualizing urban interventions, including the Berlin Memorial itself, where Eisenman refuses any form of authorship in order to anonymously deliver the project to its direct users. In other words, the value of all those experiences is revealed in the progressive construction of a subject, whose peculiarity is the ability to cross architecture as well as life, aware of the impossibility to reach any stable harbour, and that exactly this impossibility is the stable harbour to reach.

Finally, having discovered that the subject crossing the Berlin Memorial is Peter Eisenman, one can understand how, on the other hand, the real subject who produced it is in fact not Peter Eisenman. Indeed, as Toni Negri affirms: "Art is not the product of an angel but the affirmation, every time a new discovery, that everyone is an angel"15. Then, everyone who is able to cross the Berlin Memorial is really producing it: this is the little chance that this project is offering us. 
Peter Eisenman, "Giovanni Battista Piranesi: A Critical Analysis" in Barefoot on White-Hot Walls, Peter Eisenman (Wien, Ostfildern-Ruit: MAK, Hatje Cantz, 2004), 82. York, NY: Cooper-Hewitt, National Design Museum, Smithsonian Institution, 2007), 305. 1968, ed. K. Micheal Hays (Cambridge, MA, London: The MIT Press, 1998), 10. (1977), 73-80.

Jacques Derrida, Speech and Phenomena: and Other Essays on Husserl's Theory of Signs (Evanston: Northwestern University Press, 1973), 156. Minnesota Press, 1993), 152-158. authors. 
Agamben, Giorgio. Stanzas: Word and Phantasm in Western Culture. Minneapolis: University of Minnesota Press, 1993.

Agamben, Giorgio. “Die zwei Gedächtnisse.” Die Zeit, 19/2005.

Benjamin, Walter. Illuminations. New York: Harcourt Brace, 1968.

Derrida, Jacques. Speech and Phenomena: and Other Essays on Husserl's Theory of Signs. Evanston: Northwestern University Press, 1973.

Eisenman, Peter. Giuseppe Terragni: Transformations, Decompositions, Critiques. New York: The Monacelli Press, 2003.

Eisenman, Peter. "Giovanni Battista Piranesi: A Critical Analysis." In Barefoot on White-Hot Walls. Wien, Ostfildern-Ruit: MAK, Hatje Cantz, 2004.

Eisenman, Peter. The Formal Basis of Modern Architecture. Baden: Lars Müller, 2006.

Eisenman, Peter. "Piranesi and the City." In Piranesi as Designer, edited by Sarah E. Lawrence. New York, NY: Cooper-Hewitt, National Design Museum, Smithsonian Institution, 2007.

Negri, Toni. Arte e multitudo. Rome: DeriveApprodi, 2014.

Tafuri, Manfredo. "The dialectic of the Avant-Garde: Piranesi and Eisenstein." In Oppositions 11 (1977): 73-80.

Tafuri, Manfredo. The Sphere and the Labyrinth. Cambridge, MA: The MIT Press, 1987.

Tafuri, Manfredo. "Toward a Critique of Architecture Ideology." In Architecture Theory since 1968, edited by K. Micheal Hays. Cambridge, MA, London: The MIT Press, 1998.

Virno, Paolo. Convenzione e materialismo: L'unicità senza aura. Rome: DeriveApprodi, 2011. 


\section{PITER AJZENMAN,}

\section{ILI KAKO ELIMINISATI ONO ŠTO ČOVEK POSTANE}

\section{Jörg H. Gleiter}

Piter Ajzenman je Ikar post-avangardne arhitekture koji se može pohvaliti brojnim visoko cenjenim, kontroverznim objektima - kao što su Spomenik ubijenim Jevrejima Evrope u Berlinu i Ciudad de la Cultura de Galicia u Santijagu de Kompostela. Kako eliminisati ono što čovek postane-ovo je jedan od načina da se rezimira jedna od presudnih odlika Ajzenmanove arhitektonske prakse: nestanak autora. Pokazujući svoj prezir prema individualnom stilu u umetnosti, Ajzenman je u debatama o arhitekturi redovno potezao pitanje Mišela Fukoa: „Šta je pisac?” Međutim, smrt autora - „la mort de l'auteur” koju je prvi put pomenuo Roland Bart - nije bila sama sebi svrha po Ajzenmanu. Zato što jedino pitanje koje sledi:,Šta je kritika?”, osvetljava ulogu eliminacije autora u negativnosti estetike Ajzenmanove arhitektonske prakse: to je dijalektika kritike razuma i epistemologije. U tom smislu, Ajzenmanova teorija arhitekture predstavlja važan-ako ne nekontroverzan-doprinos kritičkoj filozofiji arhitekture.

KLJUČNE REČI: PITER AJZENMAN, FILOZOFIJA ARHITEKTURE, KRITIČKA TEORIJA, AUTORSTVO, DEKONSTRUKCIJA, PROJEKTOVANJE

OPERATIVNE RAZLIKE.

\section{AJZENMAN, TAFURI I LEKCIJA PIRANEZIJA}

\section{Gabriele Mastrigli, Alessandro Toti}

Piter Ajzenman je arhitekta. Iako povezana sa interesovanjem za razne oblike, oblast njegovog delovanja obuhvata istraživanje teorijskog osnova arhitektonske discipline. Arhitektura, kao artefakt i kao projekat, može da se posmatra kao najočiglednija reprezentacija tradicionalne opozicije zapadne metafizike: odsustva i prisustva. Stoga je zadatak arhitekte, prema Ajzenmanu, da analitički interveniše u ovom dijalektičkom stanju i učini ga operativnim.

Sa ove tačke gledišta, Ajzenmanov pristup disciplini - kao i čitav njegov, celoživotni arhitektonski razvojni put - posmatra se u svetlu dela Đovanija Batiste Piranezija. Otišavši dalje od kritike italijanskog istoričara arhitekture Manfreda Tafurija, Ajzenman je istraživao mogućnost novog tumačenja dijalektike između pozitivnog i negativnog, izbravši pojam zemljišta kao samog mesta ove opozicije. Berlinski Spomenik ubijenim Jevrejima Evrope nudi konačnu reprezentaciju ove dijalektike, čime otvara mogućnost daljeg, neuporedivog rada na njoj.

KLJUČNE REČI: ARHITEKTURA, RAZLIKE, ANALIZA, PROJEKAT, DIJALEKTIKA, REPREZENTACIJA, JEZIK, MONTAŽA, TRAG, ZEMLJIŠTE, SUBJEKT. 
DIGITALNO :

OD KOMPLEKSNOSTI DO JEDNOSTAVNOSTI - I NATRAG

\section{Mario Carpo}

Na početku digitalnog prevrata u ranim 90-tim godinama, digitalno inteligentna arhitektura je uopšteno smatrana krivolinijskom, oblom i modernom. Zašto? Računari su izuzetno svestrane mašine, ali koje ne pokazuju estetičke preferencije. Svakako da Piter Ajzenman, koji je jedan od izumitelja digitalizovanog pravca i 90-tim, nije imao ovo na umu. I zašto se danas stil/pravac digitalno inteligentne arhitekture ponovo menja?

Ovo su (neka od) pitanja koja su obrađena u ovom kratkom radu koji ispituje zašto i kako digitalno kao alat uključuje, ovladava i proizvodi kompleksnost.

KLJUČNE REČI: DIGITALNO, SPLAJNOVI / KRIVE, ALAT, KOMPLEKSNOST, AJZENMAN

\section{ŠTA JE ARHITEKTONSKO ISTRAŽIVANJE DANAS \\ I GDE JE OSNOV?}

\section{Djordje Stojanović}

Zašto graditi velike objekte od gumica sa studentima arhitekture? Na koji način je taj poduhvat povezan sa arhitektonskim obrazovanjem? I ako objekti od gumica nisu ni zgrade, ni modeli, već neka vrsta eksperimenata, kakvu vrstu znanja relevantnog za građevinsku industriju i izgrađeno okruženje oni generišu? Ovo su neka od pitanja koja su postavljena na konferenciji "ISSUES? Concerning the projects of Peter Eisenman" /PITANJA? U vezi sa projektima Pitera Ajzenmana/ koja je održana u Beogradu, u novembru 2013. Ona su povezana sa nizom projektantskih istraživačkih projekata koji su nedavno završeni na Arhitektonskom fakultetu, Univerziteta u Beogradu, i koji su dokumentovani u tematskom izdanju Srpskog arhitektnoskog žurnala pod naslovom „Arhitektonsko obrazovanje u postdigitalnom dobu” koje je objavljeno nezavisno od, ali skoro istovremeno sa održavanjem konferencije. U skladu sa argumentima iznetim u toj publikaciji, ovaj rad će prikazati neke od relevantnih i opšteprihvaćenih teorija i manifesta koji se odnose na metodologije projektantskog istraživanja, pružajući osnov za tekući rad na Arhitektonskom fakultetu, Univerziteta u Beogradu.

KLJUČNE REČI: ARHITEKTONSKO ISTRAŽIVANJE, UMETNIČKO ISTRAŽIVANJE, ISTRAŽIVANJE KROZ PROJEKAT, ISTRAŽIVANJE ZASNOVANO NA PRAKSI 